\title{
Impact of Climate Change on Water Resources of Dokan Dam Watershed
}

\author{
Ali Nasser Hilo ${ }^{1}$ Fouad Hussein Saeed ${ }^{2}$, Nadhir Al-Ansari ${ }^{3 *}$ \\ ${ }^{1}$ Civil Engineering Department, Wasit University, Kut, Iraq \\ ${ }^{2}$ Ministry of Water Resources, Kut, Iraq \\ ${ }^{3}$ Lulea University of Technology, Lulea, Sweden \\ Email: dralinasser@uowasit.edu.iq, fouadhusseinsaeed@gmail.com, *nadhir.alansari@ltu.se
}

How to cite this paper: Hilo, A.N., Saeed, F.H. and Al-Ansari, N. (2019) Impact of Climate Change on Water Resources of Dokan Dam Watershed. Engineering, 11, 464-474. https://doi.org/10.4236/eng.2019.118033

Received: July 27, 2019

Accepted: August 19, 2019

Published: August 21, 2019

Copyright (C) 2019 by author(s) and Scientific Research Publishing Inc. This work is licensed under the Creative Commons Attribution International License (CC BY 4.0).

http://creativecommons.org/licenses/by/4.0/

\begin{abstract}
Lesser Zab is one of the most important tributaries of Tigris River. During the last few decades, the streamflow significantly decreased for long periods followed by extensive flood in short periods. This study aimed to quantify the impact of climate change on streamflow at Dokan Dam until year 2050 using SWAT model based on the scenario of medium emission (A1B) and five climate projection models. SWAT run using Climate Forecasting System Reanalysis (CFSR) was used as weather input data then calibrated and validated on monthly time step for the period from 1980 to 2013 with Nash-Sutcliff Efficiency (NSE) of 0.73 and determination coefficient (R2) 0.73 for calibration processes. The data of this period is more reliable. The result indicated to a significant decrease on the projected streamflow until year 2050 with average streamflow for the six climate models of $167 \mathrm{~m}^{3} / \mathrm{sec}$ in past compared with the observed streamflow of $176.5 \mathrm{~m}^{3} / \mathrm{sec}$ for the base period (1980-2013). In addition, the study shows that most runoffs come from Iranian part of the Dokan Dam Watershed with $65 \%$ of total simulated runoff. It is highly recommended to improve the efficiency of water using for current and future water projects to meet the expected water shortage.
\end{abstract}

\section{Keywords}

Lesser Zab, Climate Change, SWAT, Watershed Modeling

\section{Introduction}

The increased concentration of greenhouse gases in the atmosphere leads to a significant change in climate [1]. The hydrologic pattern will be affected by this change in climate. For natural conditions, climate can be changing in specific pat- 
tern trend. However, during the last century, a rapidly changing has occurred in global climate that presented by increasing in surface air temperature and decreasing in precipitation volume. The climate change may lead to unexpected impacts on the characteristics of watershed hydrology like evaporation, streamflow and sedimentation. The natural conditions and human activities are the essential cause of this rapid chaining [2]. The climate change in hydrology can be addressed as long period of drought followed by extensive flood in short term period [3]. The prediction of climate change impacts in hydrology is related to the method of climate change estimation such as scenarios of greenhouse emission, downscaling method and general circulation model (GCMs). The uncertainty can be eliminated using multiple emission scenarios, GCMs and downscaling methods [4] [5] [6]. The uncertainty in the estimation of future climate is a major restriction to strategic planning for future projects related to hydrology [7]. Therefore, the prediction of watershed hydrology could explicate the result of multiple feeds of hydrologic model.

During the last few decades, Iraq faced extreme climate events represented as severe drought recorded between 2007 and 2009 followed by heavy rainfall occurred in a few months in southern parts of Iraq with almost two times of normal records [8]. Admo et al. [9] applied six General Circulation Models (GCMs) in SWAT model to investigate the impact of climate change on water resources of Tigris River under three scenarios of future climate change which are A2, A1B and $\mathrm{B} 1$ of highest, medium and lowest. They summarized that the precipitation will decrease in overall five tributaries (Khabour, Greater Zab, Lesser Zab, Adhaim and Diyala) of Tigris River Basin, at the same time meaning the surface and ground water will decrease as the reflection of increasing temperature and decreasing in precipitation. It is recommended to investigat the impact of climate change for each tributary alone. Abbas et al. [10] used SWAT to quantify the impact of climate change in Lesser Zab River, they indicated that the blue water will decrease by the range from $8 \%$ to $43 \%$ in 2046 . In addition, the green water will decrease by $5 \%$ to $24 \%$ in 2046 under A1B scenario. Abbas et al. [11] explored the relationship between climate change and its impact on water resources of Tigris River tributaries using SWAT model. The results showed that the precipitation will be reduced by $12.6 \%$ and $21 \%$ in the period from 2049 to 2069 and distant the period from 2080 to 2099 futures, respectively under RCP8.5. Consequently, the blue water will decreases by $22.6 \%$ and $40 \%$ under RCP8.5, $25.8 \%$ and $46 \%$ under RCP4.5, and 34.4\% and 31\% under RCP2.6 during the periods from 2049 to 2069 and 2080 to 2099, respectively. Ali et al. [12] used Sen's slope and the Mann-Kendall test to assess the streamflow trend of Lesser Zab River for the period 1964 to 2013. They indicated that stream flow would decrease by 5.09 $\mathrm{m}^{3} /$ month in April and $1.06 \mathrm{~m}^{3} /$ month in November with annual rate of decreasing $1.9 \mathrm{~m}^{3} /$ year. Wasimi et al. [13] also used SWAT model to show the impact of climate change in Tigris River for mid-term and long-term period from 2049 to 2069 and from 2080 to 2099, respectively. The result indicated that the 
Adhaim and Diyala Rivers (near Lesser Zab River) will face serve drought in future, also, they refer to the ability of mitigation and adaption of climate change reflections. Abbas et al. [11] investigated the impact of climate change in Iraq, firstly, the study investigated the capabilities of five hydrologic models which are SWAT, CREAMS, WEPP, AGNPS, and EUROSEM. SWAT was selected model as the high capabilities in water resources and climate change modelling. Zekâi Şen [14] studied the runoff estimation in upper Tigris River in Turkey under impact of climate change, the researcher used spatial dependent function for future scenario of precipitation projection at ground weather stations also, the study employed GCMs of A2 scenario in runoff modelling. The result of this study showed that precipitation will decreased into $12.5 \%$ by year 2021 and $26 \%$ by year 2030. In addition, the runoff will decrease into 30\% after year 2040. Ministry of Foreign Affairs, Netherland (MoFAN) [15] reported the climate change projection by 2050 in Iraq: increasing in mean annual temperature by $2^{\circ} \mathrm{C}$, more heat waves, decreasing of rainfall by $9 \%$ especially in winter and decreasing in average runoff into $22 \%$. Also MoFAN indicated to the impact of this changing in climate will reflected into: long drought period, increasing in flood occurrences and more desertification.

All research work concerning climate change on the Middle East region suggests that there will be reduction in the flow of the rivers. However, no detailed analysis on all rivers was given. This study, aimed to quantify the impact of climate change represented by precipitation and surface air temperature on the streamflow in Dokan Dam Watershed using most popular climate models named gfdl_cm2_1.1, giss_model_e_r.1, cnrm_cm3.1, mri _cgcm2_3_2a.1, miub_echo_g.1 and bccr_bcm2_0.1 were applied in t [16].

\section{Materials and Methods}

\subsection{Study Area}

Lesser Zab originates in the north-eastern part of Zagros Mountain in Iran (Figure 1). The Lesser Zab watershed of $19,780 \mathrm{~km}^{2}$ in area divided in to three parts, the upper part is located up stream of Dkan Dam, this part consider most contributed part of streamflow, the middle part located between Dibas Barrage and Dokan Dam, the lower part located between Dibas Barrage and joining of Lesser Zab with Tigris River. This study, focused on the upper part of Lesser Zab named Dokan Dam Watershed (DDW), which located extended with Iraq-Iran borders between latitude $36^{\circ} 51^{\prime} 16^{\prime \prime} \mathrm{N}$ to $35^{\circ} 28^{\prime} 26^{\prime \prime} \mathrm{N}$ and longitude $44^{\circ} 26^{\prime} 25^{\prime \prime} \mathrm{E}$ to $46^{\circ} 18^{\prime} 16^{\prime \prime E}$ with total watershed area $11,600 \mathrm{~km}^{2}$ (Figure 1). The average annual flow volume of DDW is about 6 Billion Cubic Meter (BCM) which consider about $77 \%$ of the total average annual flow volume of Lesser Zab. The temperatures limits in DDW from, minimum $-12^{\circ} \mathrm{C}$ in winter to maximum $48^{\circ} \mathrm{C}$ in summer [17]. In winter, a significant amounts of snow. The region is affected by wind in almost, due to the mountains that surround it. To the north, there are Goizha Mountains and to the south the Chwarta. Annual precipitation along the 


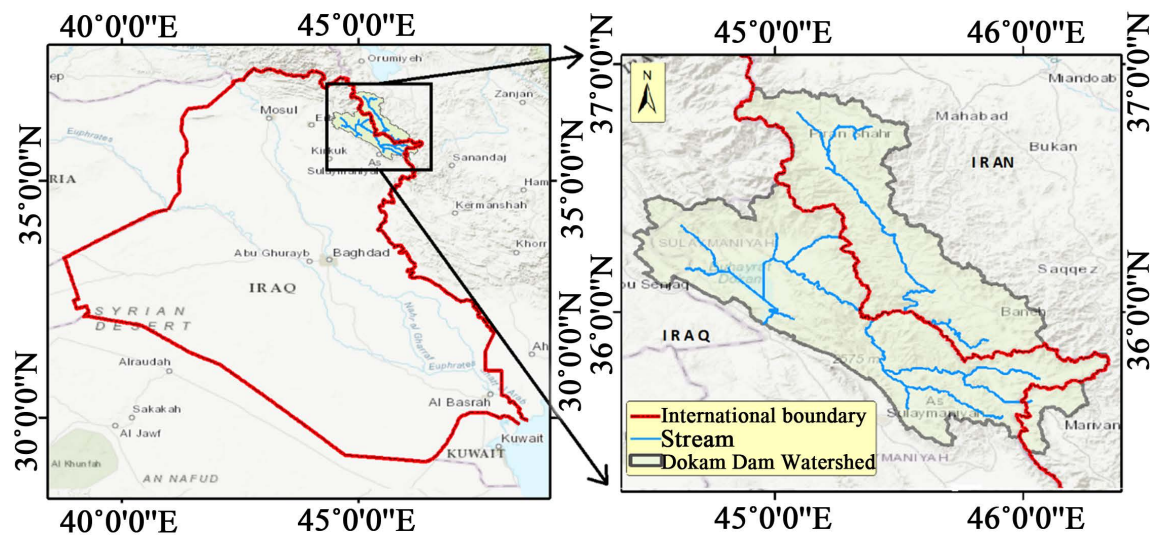

Figure 1. Location map for the study area.

course of the Lesser Zab diminishes from over $965 \mathrm{~mm}$ in the Iranian Zagros to less than $200 \mathrm{~mm}$ at the confluence with the Tigris.

\subsection{SWAT Model}

SWAT is semi-distributed physically model developed by United States Department of Agriculture-Agricultural Research Service (USDA-ARS) to quantify the impact of land management on streamflow, sediment and chemical yields in large complex watersheds with different soils, land cover-land use (LCLU) and management conditions over long periods of simulation [18].

SWAT simulates the hydrologic processes in a watershed in two independent components. The first phase is the land phase of the hydrological cycle and the other is routing phase of hydrologic cycle. The first is balanced the amount of water, sediment, nutrient and pesticide loadings to the main streams in each sub basin, and the second defines the movement of water, sediments, nutrients and organic chemicals through the channel network of the watershed to the outlet. A water balance model is simulated in the land component of SWAT [19]. SWAT divided the watershed into sub basins based on watershed topography, a further subdivision of sub basins into hydrologic response units (HRUs). Each HRU have unquiet have similar slope, LCLU and soil. The runoff estimated separately in each HRU and routed to the streams to obtain total runoff from the watershed [18]. SWAT balanced the water storage in each HRU based on the Equation (1).

$$
S W t=S W o+\sum_{i=1}^{t}\left(R_{\text {day }}-Q \text { surf }-E_{a}-W_{\text {seep }}-Q_{g w}\right)
$$

where: $S W t$ is the water content in soil $(\mathrm{mm}), S W o$ is the initial water content in soil (mm), $t$ is the time (days), $R_{d a y}$ is the precipitation amount $(\mathrm{mm})$, Qsurf is the surface runoff $(\mathrm{mm}), E_{a}$ is the evapotranspiration $(\mathrm{mm}), W_{\text {seep }}$ is the water stored in vadose $(\mathrm{mm})$ and $Q_{g w}$ is the return water from ground to surface $(\mathrm{mm})$.

\subsection{Input Data}

The following input data were applied into SWAT: 
The Digital Elevation Models (DEMs) from Shuttle Radar Topography Mission (SRTM) SRTM dataset of $90 \mathrm{~m}$ (3-arc-seconds) spatial resolution were used for watershed delineation, stream extraction and sub basins calculations according to the DEM-based method provided by SWAT.

The Moderate Resolution Imaging Spectroradiometer (MODIS) is a key instrument aboard NASA's Aqua (EOS PM) and Terra (EOS AM) satellites. The MODIS Land cover type product is produced using supervised classification algorithm of International Geosphere Biosphere Programmer (IGBP) classification, which is estimated by using database of good quality LC training sites. The training site database was selected using high resolution global images in merged with auxiliary data [20]. The MODIS land cover for the year 1992 of $500 \mathrm{~m}$ spatial resolution was applied in SWAT for DDW modeling.

The soil data were obtained from the global soil dataset of the Food and Agriculture Organization of the United Nations [21]. FAO provide data for 5000 types of soil comprising two layers ( 0 to 30 and 30 to $100 \mathrm{~cm}$ depth) at a spatial scale of 1:5,000,000. Soil chemical and physical properties such as available water content, soil texture, hydraulic conductivity, organic carbon content and bulk density for different layers of each soil are available in the FAO soil database, these database was added to SWAT database and lookup tables was prepared for soil classification in SWAT.

The Climate Forecast System Reanalysis (CFSR) dataset consists of hourly weather forecasts produced by the National Centers for Environmental Prediction (NCEP). Forecast models are updating every six hours (at 00:00, 06:00, 12:00 and 18:00 UTC) using information from the global weather station network and satellite derived weather data. At each analysis hour, the CFSR consists of both the forecast data, estimated from the previous analysis hour, and the data from the analysis applied to update the forecast models. CFSR provides weather stations in $38 \mathrm{~km}$ horizontal spatial resolution. CFSR provides weather requirements such as precipitation, maximum and minimum temperatures, relative humidity, solar radiation, and wind speed that used in SWAT for runoff simulation [22].

The daily observed streamflow at Dokan Dam gauge station provided by Iraqi Ministry of Water Resources (MoWR)-The National Center for Water Resources Management-Baghdad for the period from 1/1/1980 to 31/12/2013. The flow within this period is dependable due to the fact that no major hydrological structures were constructed.

For this study, ArcSWAT 2012 connected with ArcGIS 10.3 was used spatially processing of input data and streamflow simulation based on past and future climate. All spatial input data were projected to WGS1984_UTM_Zone38_N.

The watershed delineated according to DEM based method into 35 sub basins with threshold sub basin area of 2000 ha. Then the LCLU and soil data were defined to SWAT database and the slopes classified into four classes (0 - 10, 10 20, $20-30$, and >30). The surface runoff was predicted by modified Soil Conser- 
vation Service curve number equation (SCS-CN), the Penman-Monteith method for estimating potential evapotranspiration (ET). All other processes were kept on default setting of SWAT model (Figure 2).

\subsection{Calibration and Validation}

SWAT Calibration and Uncertainty Programs (SWAT-CUP) is an automatic calibration program developed by (Abbaspour) especially for SWAT model calibration, validation and sensitivity analysis processes.

The SUFI-2 algorithm maps all uncertainties (parameter, conceptual model, input, etc.) on the parameter ranges and tries to capture most of the measured data within the $95 \%$ prediction uncertainty (95PPU) calculated at the $2.5 \%$ and 97.5\% levels of the cumulative distribution of an output variable obtained through Latin hypercube sampling. The goodness of fit and the degree to which the calibrated model accounts for the uncertainties are assessed by two indices: $\mathrm{R}$ factor and $\mathrm{P}$ factor. The $\mathrm{P}$ factor is a fraction of measured data bracketed by the 95PPU band. The $\mathrm{P}$ factor varies from 0 to 1 , where 1 is the highest value, that is, $100 \%$ bracketing of the measured data. The $\mathrm{R}$ factor is the average width of the 95PPU band divided by the standard deviation of the measured variable. A value less than 1 is reported to be desirable for this parameter [23]. These two indices can be used to judge the strength of the calibration. A larger $\mathrm{P}$ factor can be achieved at the expense of a larger $\mathrm{R}$ factor. Hence, often a balance must be reached between the two. When acceptable values of $\mathrm{R}$ and $\mathrm{P}$ factors are reached, then the parameter uncertainties are the calibrated parameter ranges. SUFI-2 allows usage of different objective functions such as R2 or Nash-Sutcliff efficiency (NSE) [24]. In this study, we used NSE and PBIAS (Moriasi et al. 2007) for discharge and root mean square error for crop yield [25].

\section{Results}

The result of watershed modeling showed of 35 sub basins and 826 HRUs for entire DDW. For the MODIS land cover, the DDW includes the land cover class is listed in Table 1 . The pasture occupied approximately $57 \%$ of total land cover followed by agricultural land with $31 \%$ of total watershed area.

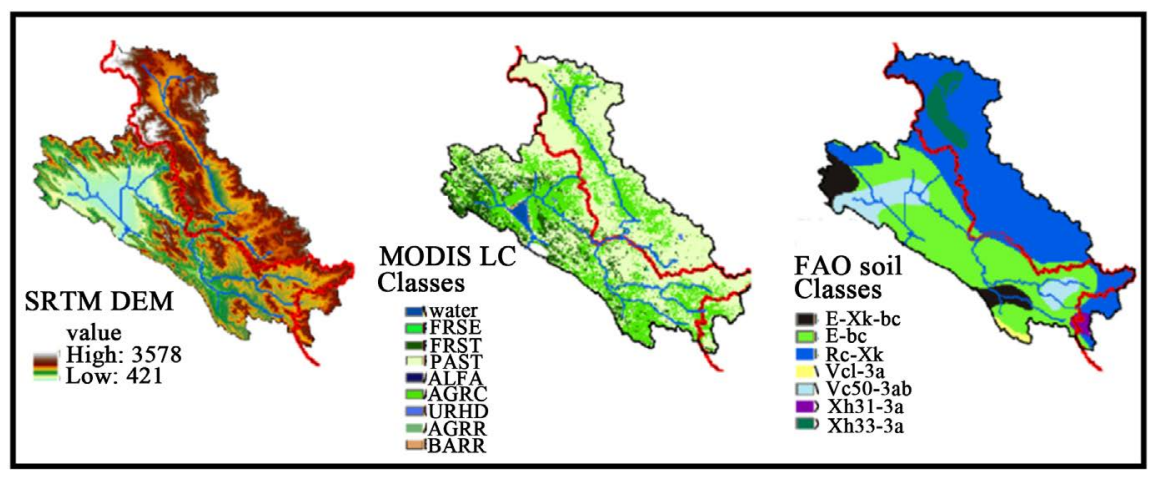

Figure 2. Input data for SWAT model. 
Table 1. The MODIS land cover types for DDW.

\begin{tabular}{ccc}
\hline Land cover-use & Legend & Percentage \% \\
\hline Forest-Mixed & FRST & 10.23 \\
Agricultural Land-Close-grown & AGRC & 31.21 \\
Residential-High Density & URHD & 0.23 \\
Water & WATR & 0.77 \\
Barren & BARR & 0.19 \\
Pasture & PAST & 57.35
\end{tabular}

Table 2 shows the calibrated parameters and the rank of each one based on the sensitivity analysis. The SCS runoff curve number parameter is the most sensitive parameter for DDW followed by groundwater delay. According to sensitivity analysis processing by SWAT-CUP, the snow parameters (parameters with ranks 7 to 10) show a significant sensitivity in DDW this is because most of participation that fall in watershed in snow mode especially winter.

The result of calibration shows a good correlation between observed and simulated with NSE and R2 of 0.73 for both and P factor and R factor of 0.85 and 1.04, respectively (Figure 3 ). In addition, the validation process also showed good correlation with NSE, R2, P factor and R factor of 0.7, 0.71, 0.82 and 0.9, respectively. This result is considerable as indicated by [26] where the NSE greater than 0.5 the simulation is satisfy while a good simulation could be considered if NSE greater than 0.75 .

The spatial distribution of streamflow sources shows the Iranian part of DDW contributed by $65 \%$ of total streamflow flow recorded in Dokan Dam.

The impact of climate change shows that the streamflow will significantly decrease for all six-climate models with significant decreasing in March and April as shown in Figure 4. The gfdl_cm2_1.1 shows most decreasing in streamflow with average future discharge 250 and $209 \mathrm{~m}^{3} / \mathrm{sec}$ in March and April compared with 400 and $415 \mathrm{~m}^{3} / \mathrm{sec}$ in the past. The miub_echo_g.1 model shows highest prediction for future streamflow among other five models with approximately the same streamflow for months from October to January while, the decreasing in predicted streamflow for months from February to April. The giss_model_e_r.1, mri_cgcm2_3_2a.1 and bccr_bcm2_0.1 models show almost the same pattern in future prediction with SWAT model.

The average annual streamflow for all six models is shown in Figure 5. The figure indicated to a significant decreasing in streamflow until 2050 with about $167 \mathrm{~m}^{3} / \mathrm{sec}$ compared with $176.5 \mathrm{~m}^{3} / \mathrm{sec}$ of average annual streamflow recorded for the period from 1980 to 2013.

This decrease due to climate change should be seriously considered. Decision makers are to put a prudent plan to minimize the effect of this reduction of the flow. Perhaps modern irrigation techniques are to be implemented as well as augmenting water using water harvesting projects and wastewater treatment and reuse techniques. 


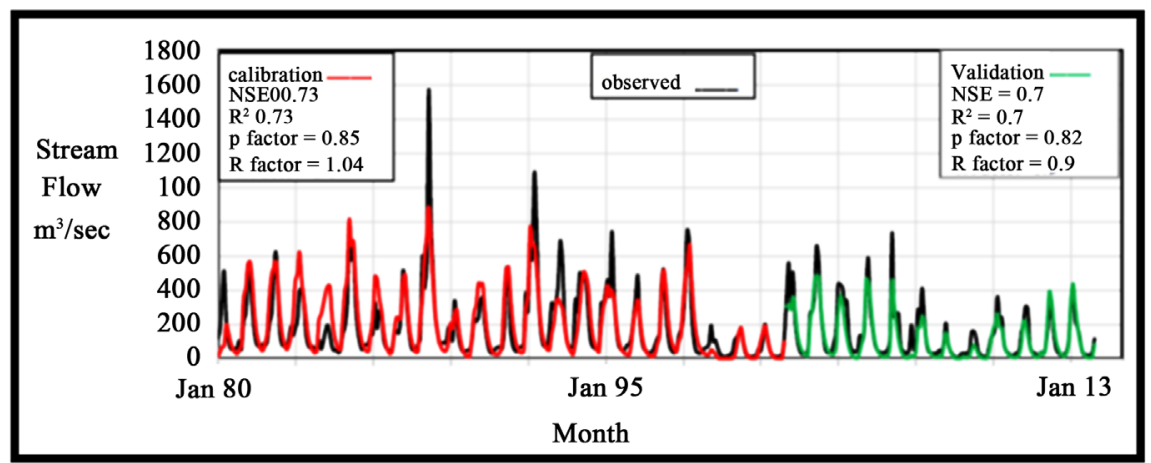

Figure 3. Result of calibration and validation.

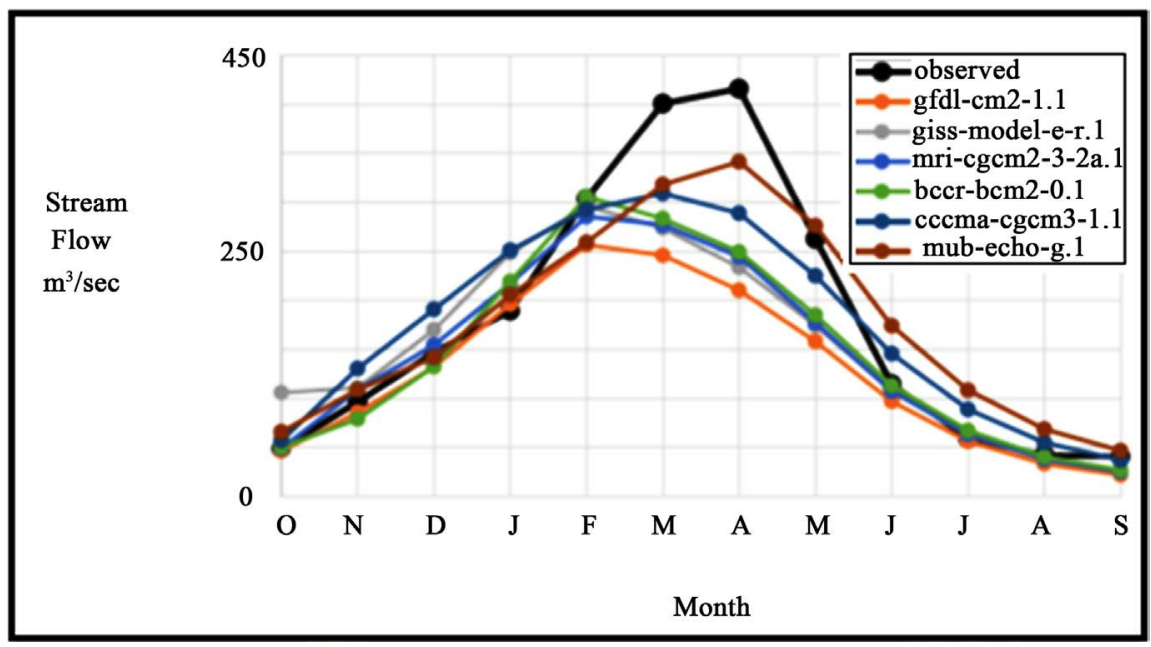

Figure 4. The predicted streamflow for future.

Table 2. The calibrated parameters of DDW.

\begin{tabular}{|c|c|c|c|}
\hline Rank & Parameter & Description & Initial range \\
\hline 1 & r__CN2.mgt & SCS runoff curve number & -0.5 to 0.5 \\
\hline 2 & v_GW_DELAY.gw & Groundwater delay & 0 to 400 \\
\hline 3 & v_ALPHA_BF.gw & Base flow alpha factor & -0.5 to 0.5 \\
\hline 4 & r_GWQMN.gw & $\begin{array}{l}\text { Threshold depth of water in the shallow } \\
\text { aquifer required for return flow to occur }\end{array}$ & 0 to 1 \\
\hline 5 & r__GW_REVAP.gw & Groundwater "revap" coefficient & -0.5 to 0.5 \\
\hline 6 & r__REVAPMN.gw & $\begin{array}{l}\text { Threshold depth of water in the shallow } \\
\text { aquifer for "revap" to occur }\end{array}$ & -0.5 to 0.5 \\
\hline 7 & v__SFTMP.bsn & Snowfall temperature & -0.5 to 0.5 \\
\hline 8 & v__SMTMP.bsn & Snow melt base temperature & -10 to 10 \\
\hline 9 & v__SMFMX.bsn & Maximum melt rate for snow during year & -10 to 10 \\
\hline 10 & v__SMFMN.bsn & Minimum melt rate for snow during the year & 0 to 10 \\
\hline 11 & r__ESCO.hru & Soil evaporation compensation factor & -0.5 to 0.5 \\
\hline
\end{tabular}




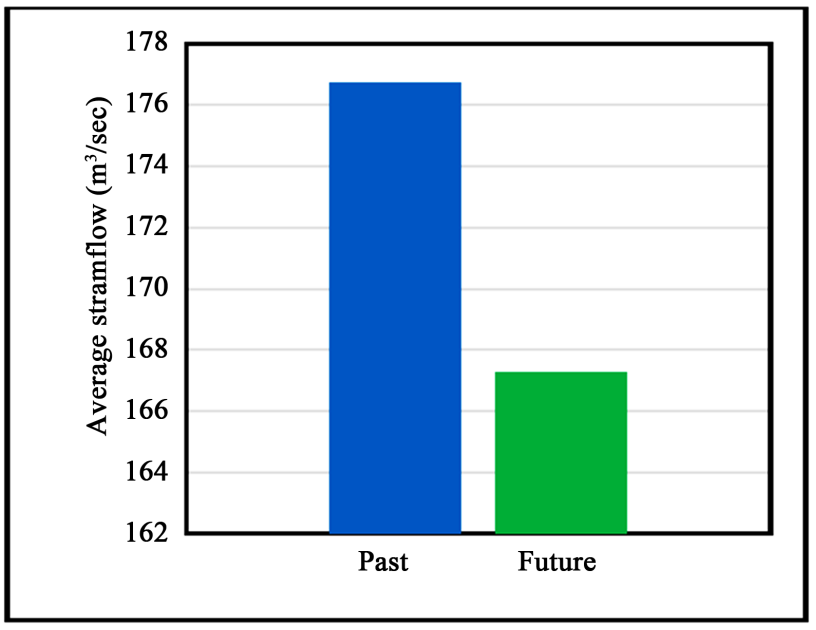

Figure 5. The average annual streamflow in the past and future.

\section{Conclusions and Recommendations}

In this study, SWAT is implemented successfully in Lesser Zab River to predict the future impact of climate change on streamflow. The CFSR weather data are considered as the reasonable source for weather input data especially in ungagged watersheds or for watersheds of missing weather data. The calibration process showed that the snow parameters have a significant sensitivity in DDW so it is recommended considering these parameters in future modeling. The study shows a decreasing in future streamflow for DDW from $176.5 \mathrm{~m}^{3} / \mathrm{sec}$ in past to 167 $\mathrm{m}^{3} / \mathrm{sec}$. It is recommended using other climate models with other scenarios of greenhouse emission to see the effect of climate change on the area. In all cases, no matter what the exact reduction of the flow is, prudent measures are to be taken to minimize the effect on the population of that area and agricultural and industrial activities. New non-conventional water resources techniques and using modern irrigation methods can greatly help to overcome the problem.

\section{Conflicts of Interest}

The authors declare no conflicts of interest regarding the publication of this paper.

\section{References}

[1] Intergovernmental Panel on Climate Chang (IPCC) (2007) The Physical Science Basis. In: Solomon, S., Qin, D., Manning, M., Chen, Z., Marquis, M., Averyt, K.B., Tignor, M. and Miller, H.L., Eds., Contribution of Working Group I to the Fourth Assessment Report of the Intergovernmental Panel on Climate Change, Cambridge University Press, Cambridge, New York, 996.

[2] Intergovernmental Panel on Climate Chang (IPCC) (2013) The Physical Science Basis. In: Stocker, T.F., Qin, D.H., Plattner, G.-K., Tignor, M.M.B., Allen, S.K., Boschung, J., Nauels, A., Xia, Y., Bex, V. and Midgley, P.M., Eds., Part of the Working Group I Contribution to the Fifth Assessment Report of the Intergovernmental Panel on Climate Change, Cambridge University Press, Cambridge, 1-1523. 
[3] Owor, M., Taylor, R.G., Tindimugaya, C. and Mwesigwa, D. (2009) Rainfall Intensity and Groundwater Recharge: Empirical Evidence from the Upper Nile Basin. Environmental Research Letters, 4, Article ID: 035009. https://doi.org/10.1088/1748-9326/4/3/035009

[4] Wilby, R.L. and Harris, I. (2006) A Framework for Assessing Uncertainties in Climate Change Impacts: Low-Flow Scenarios for the River Thames, UK. Water Resources Research, 42, W02419. https://doi.org/10.1029/2005WR004065

[5] Kingston, D.G. and Taylor, R.G. (2010) Sources of Uncertainty in Climate Change Impacts on River Discharge and Groundwater in a Headwater Catchment of the Upper Nile Basin, Uganda. Hydrology and Earth System Sciences, 14, 1297-1308. https://doi.org/10.5194/hess-14-1297-2010

[6] Chen, J., Brissette, F.P., Poulin, A. and Leconte, R. (2011) Overall Uncertainty Study of the Hydrological Impacts of Climate Change for a Canadian Watershed. Water Resources Research, 47, W12509. https://doi.org/10.1029/2011WR010602

[7] Grantham, T.E. (2018) North Coast Summary Report. California's Fourth Climate Change Assessment. Publication Number SUM-CCC4A-2018-001.

[8] UN-ESCWA (United Nations Economic and Social Commission for Western Asia) and BGR (Bundesanstaltfür Geowissenschaften und Rohstoffe) (2013) Inventory of Shared Water Resources in Western Asia. Beirut.

[9] Adamo, N., Al-Ansari, N., Sissakian, V.K., Knutsson, S. and Laue, J. (2018) Climate Change: Consequences on Iraq's Environment. Journal of Earth Sciences and Geotechnical Engineering, 8, 43-58.

[10] Nahlah, A., Wasimi Saleh, A. and Al-Ansari, N. (2016) Impacts of Climate Change on Water Resources in Diyala River Basin, Iraq. Journal of Civil Engineering and Architecture, 10, 1059-1074. https://doi.org/10.17265/1934-7359/2016.09.009

[11] Abbas, N., Saleh, A., et al. (2018) Recent Trends and Long-Range Forecasts of Water Resources of Northeast Iraq and Climate Change Adaptation Measures. Water Journal, 10, 1562. https://doi.org/10.3390/w10111562

[12] Rawshan, A., Ismael, A., Heryansyah, A. and Nawaz, N. (2019) Long Term Historic Changes in the Flow of Lesser Zab River, Iraq. Hydrology Journal, 6, 22. https://doi.org/10.3390/hydrology6010022

[13] Saleh, W., Nahlah, A. and Nadhir, A.A. (2018) Climate Change Adaptation Considerations for Agriculture for North-East Iraq. Current Investigations in Agriculture and Current Research, 2, 236-242. https://doi.org/10.32474/CIACR.2018.02.000143

[14] Şen, Z. (2018) Climate Change Expectations in the Upper Tigris River Basin, Turkey. Theoretical and Applied Climatology, 137, 1569-1585.

https://doi.org/10.1007/s00704-018-2694-z

[15] Ministry of Foreign Affairs, Netherland (MoFAN) (2019) Climate Change Profile, Iraq. Governmental Report.

[16] Maurer, E.P., Wood, A.W., Adam, J.C. and Lettenmaier, D.P. (2002) A Long-Term Hydrologically Based Dataset of Land Surface Fluxes and States for the Conterminous United States. American Meteorological Society, Boston. https://doi.org/10.1175/1520-0442(2002)015<3237:ALTHBD>2.0.CO;2

[17] Climate Forecast System Reanalysis (CFSR) Dataset (2015). http://globalweather.tamu.edu

[18] Neitch, S.L., Arnold, J.G., Kiniry, J.R. and Williams, J.R. (2005) Soil and Water Assessment Tool-Theoretical Documentation-Version. Grassland, Soil and Water Research Laboratory, Agricultural Research Service, Temple, 9-11. 
[19] Arnold, J.G., Srinivasan, R., Muttiah, R.S. and Williams, J.R. (1998) Large Area Hydrologic Modeling and Assessment-Part 1: Model Development. Journal of the American Water Resources Association, 34, 73-89. https://doi.org/10.1111/j.1752-1688.1998.tb05961.x

[20] Muchoney, D., Strahler, A., Hodges, J. and LoCastro, J. (1999) The IGBP Discover Confidence Sites and the System for Terrestrial Ecosystem Parameterization: Tools for Validating Global Land Cover Data. Photogrammetric Engineering and Remote Sensing, 65, 1061-1067.

[21] Food and Agriculture Organization (FAO) (1995) The Digital Soil Map of the World and Derived Soil Properties.

http://www.fao.org/soils-portal/soil-survey/soil-maps-and-databases/faounesco-soil -map-of-the-world/en

[22] Fuka, D.R., Todd, W.M., Charlotte, M., Arthur, T., Degaetano, Tammo, S.S. and Zachary, E.M. (2103) Using the Climate Forecast System Reanalysis as Weather Input Data for Watershed Models. Hydrological Processes, 28, 5613-5623.

[23] Abbaspour, K.C. (2011) User Manual for SWAT-CUP, SWAT Calibration and Uncertainty Analysis Programs. Swiss Federal Institute of Aquatic Science and Technology, Eawag, Duebendorf, 103 p.

[24] Nash, J.E. and Sutcliffe, J.V. (1970) River Flow Forecasting through Conceptual Models Part 1. Journal of Hydrology, 10, 282-290. https://doi.org/10.1016/0022-1694(70)90255-6

[25] Faramarzi, M., Yang, H., Schulin, R. and Abbaspour, K.C. (2010) Modeling Wheat Yield and Crop Water Productivity in Iran: Implications of Agricultural Water Management for Wheat Production. Agricultural Water Management, 97, 1861-1875. https://doi.org/10.1016/j.agwat.2010.07.002

[26] Moriasi, D.N., Arnold, J.G., Van Liew, M.W., Bingner, R.L., Harmel, R.D. and Veith, T.L. (2007) Model Evaluation Guidelines for Systematic Quantification of Accuracy in Watershed Simulation. American Society of Agricultural and Biological Engineers, 50, 885-900. 